Geological Society, London, Special Publications

\title{
An introduction to orogenic andesites and crustal growth
}

Arturo Gómez-Tuena, Susanne M. Straub and Georg F. Zellmer

Geological Society, London, Special Publications 2014, v.385; p1-13.

doi: $10.1144 / S P 385.16$

$\begin{array}{ll}\begin{array}{l}\text { Email alerting } \\ \text { service }\end{array} & \begin{array}{l}\text { click here to receive free e-mail alerts when } \\ \text { new articles cite this article }\end{array} \\ \text { Permission } & \text { click here to seek permission to re-use all or } \\ \text { request } & \text { part of this article } \\ \text { Subscribe } & \text { click here to subscribe to Geological Society, } \\ & \text { London, Special Publications or the Lyell } \\ \text { Collection }\end{array}$

\section{Notes}

(C) The Geological Society of London 2014 


\title{
An introduction to orogenic andesites and crustal growth
}

\author{
ARTURO GÓMEZ-TUENA ${ }^{1 *}$, SUSANNE M. STRAUB ${ }^{2} \&$ GEORG F. ZELLMER ${ }^{3}$ \\ ${ }^{1}$ Centro de Geociencias, Universidad Nacional Autónoma de México, \\ Querétaro 76230, Mexico \\ ${ }^{2}$ Lamont Doherty Earth Observatory of Columbia University, 61 Route 9W, Palisades, \\ NY 10964, USA \\ ${ }^{3}$ Department of Soil and Earth Sciences, IAE, Massey University, Palmerston \\ North 4442, New Zealand \\ *Corresponding author (e-mail: tuena@geociencias.unam.mx)
}

\begin{abstract}
This chapter provides an overview of the current state of research on orogenic andesites. While their importance as proxies to the evolution of the continental crust has long been recognized, andesite genesis has remained highly controversial with a broader consensus yet to be reached. The controversy is fuelled by the question of whether orogenic andesites are primary melts of slab and mantle materials, or instead derivative products of basaltic mantle melts that differentiate in the overlying crust. These hypotheses are addressed in three sections of the book devoted to slab-mantle processes, the complexities of melt differentiation at crustal levels, and models pertaining to arc crustal growth. We believe that cross-fertilization and discussion among seemingly opposite and irreconcilable hypotheses will smooth the pathway towards a holistic communal model of andesite petrogenesis.
\end{abstract}

Among the terrestrial planets, an andesitic continental crust is unique to Earth. Representing only $c$. $1 \mathrm{vol} \%$ of the silicate Earth, continents cover $c$. $40 \%$ of its surface and, by being permanently emerged above sea-level, constitute the foundation of human life and habitat. While the rate and mechanisms of continental growth have varied through time (Taylor \& McLennan 1995; Keller \& Schoene 2012), the discovery of Hadean detrital zircons demonstrates that a felsic continental crust must have existed as early as $c .4 .4 \mathrm{Ga}$ (Wilde et al. 2001; Bell et al. 2011) and, since then, it has constituted an enduring feature during planetary evolution (Harrison 2009). Yet, and despite its importance for habitability and as an archive of Earth's history, the formation of andesitic continents has long intrigued geoscientists because their very existence presents a paradox. Andesitic rocks have high abundances of silica, aluminium, sodium and potassium, but are relatively depleted in iron, magnesium, calcium and titanium. Hence, unlike basalts, they cannot be direct partial melts of the Earth's peridotite mantle. However, the andesitic crust is a major repository of incompatible elements in the silicate Earth and complements the depleted mantle, both of which were presumably separated from the Earth's primitive mantle (Hofmann 1988; Rudnick 1995; Rudnick \& Gao 2003). Yet how did an andesitic continental crust form? By which processes did these elements segregate to form a separate reservoir that is nearly as old as Earth, but fundamentally different from the crust produced by mantle melting? To date, many models of andesite crust formation have been proposed that range from sialic meteoritic infall during the early history of the Earth (Donn et al. 1965) to the gradual or episodic extraction of continental crust from the mantle through geological history (Harrison 2009; Cawood et al. 2013).

Much of the early continental crust and its genetic information have been destroyed by tectonism and erosion over the course of geological time. On modern Earth, however, andesitic magmas with remarkable compositional similarities to the average continental crust are currently being produced at convergent margins (Gill 1981; Rudnick \& Gao 2003). This observation gave rise to the 'andesite model' (Taylor 1967), which postulates continental crust formation by cycles of accretion of andesitic belts that had been created directly above orogenic areas. Over 30 years ago, the significance of orogenic andesites as an offspring of plate tectonics was recognized in the books Orogenic Andesites and Plate Tectonics (Gill 1981) and Andesites: Orogenic Andesites and Related Rocks (Thorpe 1982). Illustrating developments and state-of-the-art scientific thinking in the field of subduction-related igneous rocks, these publications became landmarks for professional geologists and scholars alike, as they provided an 
elegant explanation that linked old-school petrology with the conceptual revolution of plate tectonics. Since then, much progress has been made in refining this approach, stimulated by novel analytical advances as well as by emerging geophysical tools, both assisted by an invigorated computational power and an increasing availability of global data banks.

Most current studies on convergent margins have confirmed the causal link between plate subduction and andesite formation. The re-emergence of the short-lived cosmogenic isotope ${ }^{10} \mathrm{Be}$ in arc volcanoes provided indisputable proof that subducted sediments are recycled at convergent margins (Tera et al. 1986; Morris et al. 1990). By now, numerous studies have also demonstrated that the budget of fluid-mobile large-ion lithophile elements of arc magmas mostly derive from the various components that constitute the subducted slab, such as oceanic sediments, altered oceanic crust (AOC) and possibly abraded crust from the upper plate (Plank \& Langmuir 1993; Miller et al. 1994; Elliott et al. 1997; Kelemen et al. 2003; Plank 2005; Goss \& Kay 2006; Tonarini et al. 2011). Subducted serpentinite from either within or beneath the subducted oceanic crust contributes water that plays a vital role in mobilizing the elements from the overlying oceanic crust (Schmidt \& Poli 1998; Ranero et al. 2003; Straub \& Layne 2003; Hacker 2008). Importantly, quantifications of slab contributions showed that the elemental flux from the voluminous AOC rivals and exceeds the concomitant flux from the highly enriched, but very thin, sediment layer. Because the ratios of radiogenic isotopes of the AOC are similar to those of subarc mantle, a strong AOC flux thus buffers the flux from the sediment and effectively conceals the magnitude of the total slab flux in $\mathrm{Sr}-\mathrm{Nd}-\mathrm{Pb}-\mathrm{Hf}$ isotope space (Miller et al. 1994; Straub \& Zellmer 2012). The strong link between slab input and arc output is also emphasized by $U$ series studies that suggest recycling from slab to surface within less than a few $100 \mathrm{ka}$ and possibly even within a few thousand years (e.g. Newman et al. 1984; Elliott et al. 1997; Turner et al. 1997; Sigmarsson et al. 1998).

While there is little doubt about the efficient recycling of many trace elements, including climatically active volatiles, the origin of the distinct major element composition of arc magmas is less clear (Fig. 1). The major contention is whether andesites are primary melts of the subducted slab or the subarc mantle, or a mixture of both (Kelemen 1995; Straub et al. 2011); or alternatively, whether andesites derive from basaltic partial melts of peridotites (the basalt-input model) and are only created by secondary processing in the overlying crust (Hildreth \& Moorbath 1988; Plank \&

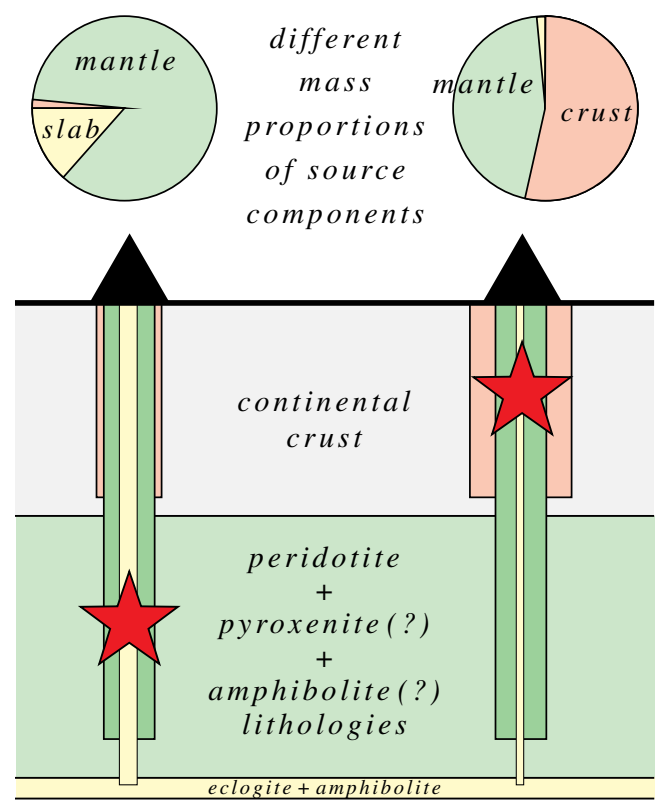

Fig. 1. Schematic diagram of the two contrasting principal locations of andesite formation (red star). Left: andesites form following hybridization of slab and mantle components in the subarc mantle; right: andesites evolve from parental arc basalts in the upper plate crust. Note different mass proportions of source components (estimated) that may result depending on mode of andesite formation.

Langmuir 1998; Annen et al. 2006; Reubi \& Blundy 2009). Because major elements make up $>99 \%$ of the melt mass, the question of slab and mantle v. a crustal origin is of key importance for the mode and rate of arc crustal growth. This is illustrated by means of the arc output equation (equation 1):

$$
\begin{aligned}
\text { elemental flux }= & \text { element abundance } \\
& \times \text { arc density } \times \text { arc growth rate }
\end{aligned}
$$

where arc density is the density of the melts, the elemental abundance is the concentration of an element in the primary melt, and the arc growth rate is the mass of melt added per unit time (given in $\mathrm{km}^{3}$ per $\mathrm{km}$ of arc length per myr). Because the range of possible arc densities is limited (c. 2.3$2.8 \mathrm{~g} \mathrm{~cm}^{-3}$ ), the elemental flux is principally a function of the arc growth rate and the element abundance, and both depend on the composition of the primary arc melts. For example, in a basalt-input model, the calculation of the mode and rate of arc crustal growth requires corrections to lower incompatible element abundances in the basaltic parental 
magmas (roughly by a factor of $2-3$ ), as well as to the original volumes of the basaltic melts that arrive at the Moho. The latter is difficult to estimate since it needs to account for the mafic residues that must be periodically delaminated from the base of the crust, an inescapable condition in order to stabilize continents with an intermediate composition over geological time (Arndt \& Goldstein 1989; Kay \& Kay 1993). Clearly, upon this model, formation of an andesitic crust will require time. On the other hand, if the flux to the Moho was an andesitic hybrid of slab and mantle components, corrections to lower incompatible element abundances, and to the effective melt volume added to crust, are less incisive and may not even be required, because there is no need for delamination or extensive melt differentiation in the crust. This would then imply fast and efficient crustal growth with a strong connectivity between arc output and slabmantle input.

The articles compiled in this book demonstrate that the dichotomy about the origin of andesitic melts from crust v. mantle is very much alive and far from being resolved. Rather than favouring a singular view, it was the goal of the editors to incite discussion to a point that may open a pathway for new research on the petrogenesis of andesite, as well as to identify its role in the context of the broader geochemical cycles of Earth.

\section{The slab-mantle connection}

\section{Slab fluids, slab melts, slab diapirs and melt-rock reactions}

At convergent margins, the downgoing sedimentary and igneous oceanic crust gradually transforms with increasing depth to greenstone, amphibolite and finally to eclogite at $c .80 \mathrm{~km}$ depth. Concomitantly, the slab expels aqueous fluids that with increasing depth grade into solute-rich fluids, partial hydrous silicic melts or supercritical fluids, and potentially 'slab diapirs' (Rapp et al. 2003; Kessel et al. 2005; Savov et al. 2005; Gómez-Tuena et al. 2008; Behn et al. 2011). 'Slab diapirs', or thermochemical slab plumes, are mechanical mixtures of hydrous mantle and partially molten basalts and sediments (Gerya et al. 2004) that may detach buoyantly from the slab and rise into the hot core of the mantle wedge (Gerya \& Yuen 2003; Behn et al. 2011; Marschall \& Schumacher 2012), and that may 'relaminate' to the base of the overriding crust (Hacker et al. 2011). Recent experimental data suggest that melting of the slab and diapirism may be the rule rather than the exception beneath arc front depths in most subduction zones (Hermann \& Spandler 2008; Klimm et al. 2008; Plank et al. 2009; Behn et al. 2011), and either mechanism can produce melts that strongly resemble andesitic arc magmas and that may add to arc crustal growth (Castro et al. 2013; Behn et al. 2011; and see also GómezTuena et al. 2013). Thus, the simplest concept is that andesite arc crust grows through addition of such slab components that may or may not be additionally modified in the mantle wedge (Ringwood 1974).

Arc volcanic rocks with the characteristics of slab melts, such as $\mathrm{SiO}_{2}>56 \mathrm{wt} \%$, fractionated heavy rare earth element (HREE) and high $\mathrm{Sr} / \mathrm{Y}$ ratios (Defant \& Drummond 1990), have been found in many arc settings, and are broadly referred to as 'adakites' after their type locality of Adak Island in the Aleutians (Kay 1978). In a landmark study, Defant \& Drummond (1990) proposed that adakitic melts were linked to the subduction of young $(<25 \mathrm{Ma})$ and warm oceanic crust, for it was only there that the thermal structure of the modern Earth allowed for melting of subducted metabasalts. Later studies, however, showed that adakitic rocks are found in a variety of settings that depart from warm slab geotherms, or from convergent margins (see Castillo 2012 for a recent overview). Other authors have also shown that adakitic compositions can be produced by crustal differentiation (Müntener et al. 2001; MacPherson et al. 2006; Alonso-Perez et al. 2009; Zellmer et al. 2012). For instance, Zellmer et al. (2012) recently proposed that the adakitic signatures in western Honshu were caused by fractional crystallization in the presence of garnet that was stabilized in the lower crust by the comparatively higher water abundances of the parental melts. However, a contribution by Shibata et al. (2013) confronts the fractionation hypothesis of Zellmer et al. (2012) for the SW Japanese arc, and relates the emergence of arcfront adakites in northern Kyushu to the abrupt change in the age of the subducted slab from the Philippine Sea in the south to the younger and hotter Miocene plate in the north. While these studies demonstrate that the term 'adakite' has indeed lost much of its genetic connotation, it is also true that their petrogenetic significance is still far from being resolved.

All the same, and despite the widespread occurrence of adakites, there is no doubt that the majority of modern arc volcanics lack tell-tale garnet signatures that may be traced to slab melting at eclogite facies conditions. The absence of garnet signatures is a key argument in models that propose most andesites to ultimately derive from basaltic parental melts that contain only a few mass-per cent of slab contributions (Gill 1981; Tatsumi \& Eggins 1995). Intriguingly, some experimental evidence shows that peridotite melting under hydrous conditions can produce andesite melts with $\mathrm{SiO}_{2}$ abundances 
as high as $60 \mathrm{wt} \%$ (Baker et al. 1994; Hirose 1997; Gaetani \& Grove 1998; Carmichael 2002). However, primitive magnesian andesites are only produced by hydrous melting if (a) the temperatures and pressures of the last equilibration are extremely low $\left(<1000{ }^{\circ} \mathrm{C}\right.$ and $\left.1 \mathrm{GPa}\right)$, (b) water contents are kept at levels close to saturation $(>7 \mathrm{wt} \%)$ and (c) the residual mantle has the paragenesis of a refractory harzburgite (Hirose 1997; Parman \& Grove 2004; Grove et al. 2012). Since subtle variations in these parameters will inevitably render the melts basaltic, and in view of the rarity of water contents $>7$ wt $\% \mathrm{H}_{2} \mathrm{O}$ in arc magmas (Ruscitto et al. 2012; Plank et al. 2013), andesite production by hydrous peridotite melting should be exceptionally rare in most arcs.

However, does the lack of a garnet signature in arc magmas indeed preclude a link between andesite genesis and slab melting or diapirism? Two contributions to this volume argue otherwise. First, Straub et al. (2013) present a study of young magnesian arc basalts to andesites from the central Mexican Volcanic Belt. While these rocks lack a garnet signature and have low, non-adakitic $\mathrm{Sr} / \mathrm{Y}$ ratios, it had been inferred earlier on the basis of the high-Ni olivines that they contained $>15-$ $18 \%$ of a silicic slab component consequent to melt-rock reaction in the mantle wedge (Straub et al. 2011). Here, Straub et al. (2013) show that this reaction process is capable of blending a strongly fractionated slab component (10-30\%) with steep HREE pattern with the subarc mantle in such ways that the HREE (Ho-Lu) and $\mathrm{TiO}_{2}$ remain controlled by the mantle (which produces partial melts with flat HREE and negative $\mathrm{TiO}_{2}$ anomalies) with all other elements controlled or at least significantly augmented by slab additions.

Second, Gómez-Tuena et al. (2013) suggest that the lack of a garnet signature was due to recycling by means of 'slab diapirs'. In western Mexico, garnet signatures are strongly recorded in arc-front magmas, located about $140 \mathrm{~km}$ above the subducted plate (Gómez-Tuena et al. 2011), but conspicuously absent in rear-arc andesitic stratovolcanoes, despite their location at $>300 \mathrm{~km}$ depth above one of the warmest slabs on Earth. This observation defies models of depth-progressive slab transition from amphibolite to eclogite. Moreover, over an area of $2000 \mathrm{~km}^{2}$, peripheral volcanism exhibits highly variable trace element patterns within a few kilometres of each other, suggesting a highly heterogeneous mantle source region. These observations can be explained by a model in which the subducted materials are detached from the deeper slab as buoyant diapirs and subsequently melt in the hot core of the mantle wedge at relatively shallow depths. A multitude of plumes that may partially melt at different pressures and temperatures may then create the exceptional diversity of erupted melts in western Mexico.

\section{Timescales of melt transfer from slab and mantle to surface}

An important question is the timescale of mass transfer from slab to crust and surface, as this provides unique information on the rate of arc crustal growth. The application of uranium-series isotope analysis of arc magmas in the past two decades provides strong arguments in favour of a rapid mass transfer. Uranium-series isotopes enable processes to be traced on the timescales $<350 \mathrm{ka}$ $\left({ }^{238} \mathrm{U}-{ }^{230} \mathrm{Th}\right),<150 \mathrm{ka}\left({ }^{231} \mathrm{~Pa}-{ }^{235} \mathrm{U}\right)$ and $<8 \mathrm{ka}$ $\left({ }^{226} \mathrm{Ra}-{ }^{230} \mathrm{Th}\right)$ (Condomines et al. 1988; Turner et al. 2003). Therefore, uranium-series disequilibria in young arc magmas should trace events that caused the respective parent/daughter elements in the uranium series isotope chain to fractionate. Dependent on the geochemical behaviour of the elements, however, uranium-series isotopes have been proposed to trace either release of slab fluids (Elliott et al. 1997; Turner et al. 1997; Sigmarsson et al. 1998; Zellmer et al. 2000) or the onset of slab and/or mantle melting (Avanzinelli et al. 2012). Thus, the disequilibria detectable in arc magmas imply time spans between release of the slab component and eruption in the order of at most $10^{4}-10^{5}$ years (Elliott et al. 1997), melt ascent rates of at least several metres per year (Turner et al. 2003) and possibly multiple slab dehydration events within less than 1000 years prior to eruption (Turner et al. 2000). However, these timescales must still be considered against the background of an ongoing debate on the U-series elemental behaviour. For example, $\mathrm{Pa}$ is normally considered as fluid immobile (Elliott et al. 1997; Bourdon et al. 1999) and, therefore, ${ }^{231} \mathrm{~Pa}$ excesses should be controlled by dynamic melting of the mantle (Turner et al. 1996). However, Avanzinelli et al. (2012) recently argued that a slab component probably includes significant amounts of Th and $\mathrm{Pa}$ and thus traces slab melt release at timescales of $<150$ ka prior to eruption.

Despite substantial advances in this field over the last few decades, high-precision U-series analyses remain challenging and progress is slow. The contribution by Dosseto \& Turner (2013) serves well to illustrate the promise and complexity of U-series studies. The authors report new high-precision data on previously analysed samples from Kamchatka, which results in a re-interpretation of an earlier genetic model proposed by Dosseto et al. (2003). Rather than mixing of slab fluids into the mantle wedge within $<150 \mathrm{ka}$, it is now argued that $\left({ }^{238} \mathrm{U} /{ }^{230} \mathrm{Th}\right)$ disequilibria and ${ }^{226} \mathrm{Ra}$ and 
${ }^{231} \mathrm{~Pa}$ excesses are best explained by dynamic melting of a recently $(<10 \mathrm{ka})$ metasomatized mantle source followed by late-stage overprinting in the crust. This model is thought to be superior to models of multiple dehydration events (Bourdon et al. 2003) or melting under high oxygen fugacity (Beier et al. 2010) in producing the observed U-series systematics.

\section{The role of the overriding crust}

The basalt-input model implies that orogenic andesites would not exist without the overriding crust. Clearly, the overriding crust is a physical barrier that forces ascending mantle magmas to stagnate, cool and differentiate by various processes, such as fractional crystallization, assimilation of crustal basement and mixing between stagnating and newly ascending magmas. There is also a welldocumented global correlation between crustal thickness and melt silica abundances (Leeman 1983) that holds despite the more recent discovery of common silicic rock series in intra-oceanic arcs (Kodaira et al. 2007; Haase et al. 2011; Smith 2013; Stern et al. 2013). A plethora of petrographic and geochemical studies on arc magmas, often substantiated by the presence of crustal xenoliths, also provide irrefutable evidence of melt modification in the crust (Eichelberger 1978; Davidson \& Tepley 1997; Nishimoto et al. 2005; Davidson et al. 2007; Ortega-Gutiérrez et al. 2008; Reubi \& Blundy 2009). Moreover, rare mantle xenoliths (Blatter \& Carmichael 1998) and high-Mg\# basalt magmas that lack garnet signatures demonstrate that peridotite is present in the subarc mantle and contributes to arc magma genesis.

The evolution of silicic andesitic magmas from basaltic parental melts, however, entails one significant problem: the disposal of large volumes of mafic and ultramafic cumulates. Simple mass balance calculations require mafic cumulates and restites to comprise at least half of the basaltic melt volume that crosses the Moho (Jull \& Kelemen 2001; Tatsumi et al. 2008). Because the average continental crust is andesitic, such mafic residues should be periodically removed and recycled back into the mantle in a process that is often referred to as 'delamination' or 'lithospheric foundering' (Arndt \& Goldstein 1989; Kay \& Kay 1993; Tatsumi et al. 2008; Stern \& Scholl 2010). While active foundering has been deduced from seismic profiles (Zandt et al. 2004) and interpreted to play a significant role in the magmatic evolution of the Andes (Kay et al. 2013), evidence from exposed crustal sections indicates that delamination does not seem sufficient to render an andesitic bulk continental crust (Greene et al. 2006). Indeed, other studies in active arcs even suggest that lithospheric foundering may be counterbalanced by triggering voluminous basaltic volcanism, and thus not necessarily displace the bulk crust to more felsic compositions (ElkinsTanton 2007; Mori et al. 2009).

\section{Melt evolution in the crust}

The importance of intra-crustal processing and differentiation in andesite genesis is reflected in eight contributions to this book. Two studies consider fractional crystallization a principal mechanism of crustal differentiation (Elburg et al. 2013; Smith 2013), while the other six papers emphasize the importance of melt mixing. This triage agrees with the new wealth of microbeam data that became available in recent years that invariably demonstrate the ubiquity of melt mixing on the microscopic scale of otherwise macroscopically inconspicuous rocks (Davidson \& Tepley 1997; Reubi \& Blundy 2009; Kent et al. 2010; Straub et al. 2011). The overwhelming evidence of melt mixing is noteworthy, as fractional crystallization with or without contamination - was the key concept behind the classical model of andesites as derivative melts of parental basaltic magmas in the overlying crust (Gill 1981; Hildreth \& Moorbath 1988; Plank \& Langmuir 1988).

Smith (2013) suggests that the common occurrence of high-Mg\# andesite in the late Cenozoic Papuan volcanic arc is linked to extensional tectonics, and emphasizes the importance of crustal thickness in defining fractionation assemblages. The two magma series of low-Mg\# and high-Mg\# andesites are proposed to derive from a primary basaltic magma through either high-pressure fractionation of amphibole (high-Mg\# andesites) or low-pressure fractionation of olivine and clinopyroxene (low-Mg\# andesites). Elburg et al. (2013) investigate basalt to rhyolite series from three Quaternary Aegean volcanoes, Methana, Santorini and Nisyros, that are evenly distributed within a c. $400 \mathrm{~km}$-long segment along the Aegean arc volcanic front. They suggest that dacitic and rhyolitic magmas evolve from parental basalt within the crust with only minor crustal contamination. Apatite, titanomagnetite and amphibole are recognized as important fractionating phases, whereby the variable amphibole stability at different crustal thickness is thought to control various levels of depletion of middle and heavy rare earth elements at different volcanoes.

However, while such models are qualitatively convincing, they still require confirmation by modelling of the purported liquid lines of descent (LLD) for the major element oxides. The lack of such models, evident also in other studies that provide otherwise compelling evidence for melt evolution 
by fractional crystallization (Wade et al. 2005) has several reasons. First, there is the problem of how to recognize the 'true' liquid line of descent from magma series that do not represent continuous stratigraphic sections of individual volcanoes (see also Smith 2013). Volcanic time series that should best record the LLD are even more difficult to establish from individual volcanoes that undergo multiple eruptions from various vents (see Elburg et al. 2013). Second, even if time series are recognized, mixing of newly ascending magma with stagnating crustal magma bodies (i.e. 'recharge melt mixing', see Kent 2013) may overprint and erase the original LLDs. Moreover, in two contributions to this book, Zellmer et al. (2013a, b) describe an extreme variant of recharge melt mixing from basalts (SW Japan) and andesites (Chile), in which newly ascending aphyric magmas take up crystals from previous batches of partially crystallized magmas of similar composition within the same magmatic system, that ultimately erupt as porphyritic lavas. Thus, if the crystal cargo in the rocks consists mostly of antecrysts and xenocryst, the mineral compositions may be decoupled from the melt compositions, and thus have little meaning for the LLD along which melts may evolve. Third, despite the continuous development of sophisticated algorithms, such as MELTS and its later improvements (Ghiorso \& Sack 1995; Ghiorso et al. 2002), quantitative models still fail to capture the complexities of LLDs that evolve along changing temperatures and pressures, melt $\mathrm{fO}_{2}$, volatile content and mineral/melt partitioning behaviour.

An important aspect of melt evolution by fractional crystallization with minor or negligible crustal contamination is that many key signatures of the basaltic parental melts (e.g. ratios of radiogenic isotopes and incompatible elements) are preserved until andesitic and dacitic compositions are reached. Thus, after correction for mass and abundance level, silicic arc magmas are still able to provide estimates of slab and mantle fluxes. In the alternative model of mixing of basaltic and silicic melts, such assessments are much more difficult and depend on the origin of the silicic end-member (see also Gómez-Tuena et al. 2013). The silicic endmember may have different origins, such as the ambient crust (Eichelberger 1978), a derivate melt of an earlier basalt injection into the same magma system or a combination of both (Annen et al. 2006; Reubi \& Blundy 2009). If the silicic endmember is derived from pre-existent crust, the mass and elemental abundance of juvenile mantle melts may be small, and probably less than half of the melt volume produced.

Several contributions to this book and many other published studies show that bimodality is a common characteristic of arc magmas world-wide.
Respective end-members are mafic (basalt to basaltic andesitic) and silicic (dacitic-rhyolitic), and andesites are quite often produced by melt mixing. The mixing process, however, may not be complete. For example, bimodality of dacitic and basaltic andesite magmas at the Holocene Guatemalan Volcán de Santa María is well preserved. Here, Singer et al. (2013) propose that these dacites formed by crystal fractionation from previous intrusions of basaltic andesite at $>5 \mathrm{~km}$ crustal depth over tens of thousands of years. Their eruption was ultimately triggered by newly ascending basaltic andesitic melts, which incompletely mingled during ascent, and did not yet produce intermediate andesites. Stern et al. (2013) propose a similar scenario in order to account for the strongly bimodal series of basaltic-andesites and dacite-rhyolites erupted at the Quaternary Diamante cross-chain volcanoes, which are part of the $110 \mathrm{~km}$ long Anatahan Felsic Province along the southern Mariana Volcanic arc. However, in this model, the silicic series originate from a pre-existing tonalitic middle crust that was reheated by hot and newly ascending mantle-derived magmas.

Mixing of mafic and silicic magmas can be very efficient in creating homogeneous melts. For instance, a study of phenocryst compositions of apparently homogeneous andesites from Mt Hood in the Cascades arc indicated an origin by homogenization of basaltic and silicic melts (Kent et al. 2010). In this volume, Kent (2013) further suggests that the cryptic bimodality is a consequence of 'mafic recharge' where hydrous mafic magma intrudes into a pre-existing crustal silicic magma or mush. Such 'eruption filtering' may be instrumental in the preferential eruption of only highly hybridized andesites, whereas the original silicic and mafic parental magmas are retained in the crust. Lastly, Steiner \& Streck (2013) propose that mixing of tholeiitic basaltic mantle melts with ambient crust may play a key role in the evolution of calc-alkaline andesitic magmas with their typical low $\mathrm{FeO} / \mathrm{MgO}$ at high $\mathrm{SiO}_{2}$. This claim is substantiated by the fact that it was reported in a non-subduction setting, namely the intra-continental Miocene Strawberry Volcanic Suite in proximity to the Columbia River flood basalt province in the western USA.

\section{Residence times of magmas in the crust}

An important complement to understanding the processes of crustal differentiation is the question of residence times of melts in the crust. Do erupted melts pass rapidly through the crust or is there an extended stagnation period? Within the past two decades, a wide array of geochronometers have become available, which include U-series 
disequilibrium studies of bulk rocks and mineral separates (e.g. Condomines et al. 2003), crystal size distribution analysis (e.g. Cashman \& Marsh 1988; Higgins 1996), chemical diffusion profiles of minerals (e.g. Lasaga 1983; Costa et al. 2003; Zellmer et al. 2003; Morgan \& Blake 2006; Ruprecht \& Plank 2013), the study of isotopic variations between growth zones within individual crystals (e.g. Davidson \& Tepley 1997) and U-Th dating of accessory minerals (e.g. Schmitt 2011).

Although the determination of melt residence times in the crust is still a developing field where results do not always agree, it is evident that the timescales of magma storage in the crust are quite variable. Thus far, the data provide evidence for rapid passage as well as extended time of melt migration and differentiation, as magma bodies may evolve within $c .10^{3}-10^{5}$ years. There are also distinct variations among different lithologies: porphyritic lava domes in intermediate to felsic systems may record short timescales reflecting lastminute mixing at the onset of eruption, but also complex and protracted crystallization episodes of the order of tens of thousands of years or longer (Zellmer 2008). Mafic melts may traverse the crust more rapidly, despite frequently recording uptake of old cumulate crystals (Zellmer et al. 2005). Extremely rapid ascent of some arc magmas from great depths to the surface (within a few days) has been suggested on the basis of seismic studies (Blot 1972; Fedotov et al. 1983) and the preservation of ultramafic hornblende-peridotite mantle xenoliths in their host magmas (Blatter \& Carmichael 1998). The two Zellmer et al. $(2013 a, b)$ contributions in this volume provide further, albeit circumstantial, evidence for extremely rapid melt transfer from depth through the crustal lid.

\section{Temporal evolution and crustal growth}

Volcanic arcs are active over tens of millions of years, which means that the timescales of arc crustal growth well exceed the timescales of crustal differentiation. Thus, a simple way to assess a causal relation between arc crust thickening and melt $\mathrm{SiO}_{2}$ abundances in orogenic andesites is to observe arc evolution through time. Three contributions to this book discuss the complex interplay between evolving tectonic parameters and rock compositions through time. Kay et al. (2013) review the Miocene to Holocene arc magmatism of the central Argentine and Chilean Andes, Yoshida et al. (2013) present a detailed summary of the Cenozoic evolution of the NE Japan arc and Bryan et al. (2013) report the occurrence of early to middle Miocene syn-extensional andesitic magmatism in the context of the Cenozoic evolution of the Gulf of California. At the Andean margin, Neogene magmas show the influence of crustal thickening and foundering, plateau uplift and landward frontal arc migration, subduction erosion and slab-mantle mixing over a continuously changing Benioff zone (Kay et al. 2013). The NE Japan arc is characterized by clear secular changes of mode of magmatic activity and style of magma plumbing system, which affect eruption volumes and magmatic compositions in response to geotectonic evolution and mantle wedge convection (Yoshida $e t$ al. 2013). In the Mexican margin, a middle Miocene phase of calc-alkaline andesite magmatism occurs in an active rift environment without evidence of concurrent plate subduction, further questioning the belief that the orogenic andesites are confined to active convergent margins (Bryan et al. 2013; and also see Steiner \& Streck 2013).

All of these studies illustrate the complexity of andesite formation that varies strongly within and among different settings. However, they have one remarkable common factor, namely the lack of unidirectional trends of arc chemistry with time that would be interpreted as an effect of increasing crustal thickening and maturing. These findings agree with results from the $50 \mathrm{myr}$ Izu-Bonin Mariana arcs in the NW Pacific, which has been well investigated for temporal trends (Lee et al. 1995; Straub 2003; Straub et al. 2010; Ishizuka et al. 2011). The results suggest that crustal thickness is not a singular controlling factor on the composition of orogenic andesites, but merely one of many controlling factors.

\section{Summary and outlook}

The contributions to this book mostly confirm and expand the notion that a fundamental connection exists among convergent margins, andesites and continents (Gill 1981; Thorpe 1982). At the same time, it is also obvious that the genesis of orogenic andesites remains enigmatic and that no consensus model exists. Because of substantial progress with respect to confirming the validity, magnitude and efficiency of slab recycling, however, it is more important than ever to determine mass fluxes associated with convergent margin volcanism. The rate and mode of arc crustal growth is intimately linked with the flux of elements - including climatically active gases - that are perpetually cycled through the subduction interface and, as such, can strongly influence the evolution of global climate (Kennett \& Thunell 1977; Huybers \& Langmuir 2009; Kutterolf et al. 2013).

A hallmark of orogenic andesites is their consistent calc-alkaline composition despite highly variable geological parameters, such as crustal 
thickness and architecture, convergence rate, thermal structures, age of subducted crust, and so on. In view of such constancy, it seems unlikely that more than one fundamental process produces orogenic andesites and, in particular, not two processes that are so different, such as the slab-mantle models and the crustal differentiation (basalt-input) model outlined above. Does the diversity observed reflect innumerous variations of one of these models, or possibly a complex combination of both? How can such questions be answered?

Although the contributions to this book do not provide a consensus model of orogenic andesite formation, they show what it is needed at this junction to achieve further progress. The core of the problem lies with the fact that the genetic process cannot be directly observed, but needs to be inferred indirectly from the mixed and processed 'products' of andesite formation, namely the erupted magmas. This book highlights the diverse models and hypotheses by which these data are interpreted, and illustrates the lack of consensus about the mechanisms and loci of melt differentiation. For example, while the dominance of melt mixing is obvious, it is not clear where and how the magmas differentiate (i.e. evolve a broader spectrum of basaltic to dacitic-rhyolitic rocks) in the first place. Does this happen below or above the Moho? Is this done by melting of various slab and primary and secondary mantle lithologies under the subduction influence, or does this happen by fractional crystallization and/or contamination in the overriding crust?

In the past decades, the widely supported basalt-input model triggered many studies with a focus on the most mafic series in arc settings, on the assumption that these best reflect initial signals of slab and mantle processes. However, the possibility that much of the geochemical diversity found in arcs is created by sub-Moho processes opens up a different perspective, and emphasizes the need to study equally all mafic and evolved end-members without a preconceived notion of a probable origin. Regardless of a crustal v. mantle origin, silicic arc magmas must carry vital genetic information that is an essential complement to their basaltic counterparts. Basaltic to silicic magma series emitted from individual vents should be ideally suited to unravelling the processes of melt differentiation, and to obtain insights through quantitative models that are essential to understanding the genesis of orogenic andesites and the global continents.

We would like to acknowledge all colleagues who have contributed to our understanding of orogenic andesites. We are grateful for the opportunity to present some of this progress within a dedicated volume. We thank R. Gertisser for a very positive and encouraging review of the initial book proposal, and all reviewers who provided timely and constructive feedback. This chapter benefited from discussions with C. Annen, T. Plank and F. Ortega-Gutiérrez. T. Anderson and A. Hills provided administrative support throughout the editorial process. SMS acknowledges support from the US National Science Foundation for her research on arcs. GFZ acknowledges funding by the Global Volcanism Program for a research fellowship at Smithsonian's Natural Museum of Natural History. AGT's research on andesites was funded by PAPIIT-UNAM project IN107810.

\section{References}

Alonso-Perez, R., Müntener, O. \& Ulmer, P. 2009. Igneous garnet and amphibole fractionation in the roots of island arcs: experimental constraints on andesitic liquids. Contributions to Mineralogy and Petrology, 157, 541-558, http://dx.doi.org/10.1007/ s00410-008-0351-8

Annen, C., Blundy, J. D. \& Sparks, R. S. J. 2006. The genesis of intermediate and silicic magmas in deep crustal hot zones. Journal of Petrology, 47, 505-539, http://dx.doi.org/10.1093/petrology/egi084

ARndT, N. \& GoldSTeIN, S. 1989. An open boundary between lower continental crust and mantle: its role in crust formation and crustal recycling. Tectonophysics, 161, 201-212.

Avanzinelli, R., Prytulak, J., Skora, S., Heumann, A., Koetsier, G. \& Elliott, T. 2012. Combined ${ }^{238} \mathrm{U}-{ }^{230} \mathrm{Th}$ and ${ }^{235} \mathrm{U}-{ }^{231} \mathrm{~Pa}$ constraints on the transport of slab-derived material beneath the Mariana Islands. Geochimica et Cosmochimica Acta, 92, 308-328, http://dx.doi.org/10.1016/j.gca.2012.06.020

Baker, M., Grove, T. L. \& Price, R. 1994. Primitive basalts and andesites from Mt. Shasta region, N. California: products of varying melt fraction and water content. Contributions to Mineralogy and Petrology, 118, 111-129.

Behn, M. D., Kelemen, P. B., Hirth, G., Hacker, B. R. \& Massonne, H.-J. 2011. Diapirs as the source of the sediment signature in arc lavas. Nature Geoscience, 4, 641-646, http://dx.doi.org/10.1038/ngeo1214

Beier, C., Turner, S. P., Sinton, J. M. \& Gill, J. B. 2010. Influence of subducted components on back-arc melting dynamics in the Manus Basin. Geochemistry, Geophysics, Geosystems, 11, http://dx. doi.org/10.1029/2010GC003037

Bell, E. A., Harrison, T. M., McCulloch, M. T. \& YounG, E. D. 2011. Early Archean crustal evolution of the Jack Hills Zircon source terrane inferred from $\mathrm{Lu}-\mathrm{Hf},{ }^{207} \mathrm{~Pb} /{ }^{206} \mathrm{~Pb}$, and $\delta^{18} \mathrm{O}$ systematics of Jack Hills zircons. Geochimica et Cosmochimica Acta, 75, 4816-4829, http://dx.doi.org/10.1016/j. gca.2011.06.007

Blatter, D. L. \& Carmichael, I. S. E. 1998. Hornblende peridotite xenoliths from central Mexico reveal the highly oxidized nature of subarc upper mantle. Geology, 26, 1035-1038.

BLot, C. 1972. Volcanisme et séismes du manteau supérieur dans l'Archipel des Nouvelles-Hébrides. Bulletin Volcanologique, 36, 446-461, http://dx.doi.org/10. 1007/BF02597120 
Bourdon, B., Turner, S. \& Allègre, C. 1999. Melting dynamics beneath the Tonga-Kermadec Island Arc Inferred from ${ }^{231} \mathrm{~Pa}-{ }^{235} \mathrm{U}$ systematics. Science, $\mathbf{2 8 6}$, 2491-2493, http://dx.doi.org/10.1126/science.286. 5449.2491

Bourdon, B., Turner, S. \& Dosseto, A. 2003. Dehydration and partial melting in subduction zones: constraints from U-series disequilibria. Journal of Geophysical Research: Solid Earth, 108, http://dx. doi.org/10.1029/2002JB001839

Bryan, S. E., Orozco-Esquivel, T., Ferrari, L. \& López-Martínez, M. 2013. Pulling apart the Mid to Late Cenozoic magmatic record of the Gulf of California: is there a Comondú Arc? In: GómezTuena, A., Straub, S. M. \& Zellmer, G. F. (eds) Orogenic Andesites and Crustal Growth. Geological Society, London, Special Publications, 385. First published online July 31, 2013, http://dx.doi.org/10. $1144 /$ SP385.8

Carmichael, I. S. E. 2002. The andesite aqueduct: perspectives on the evolution of intermediate magmatism in west-central $\left(105^{\circ}-99^{\circ} \mathrm{W}\right)$ Mexico. Contributions to Mineralogy and Petrology, 143, 641-663.

Cashman, K. V. \& Marsh, B. D. 1988. Crystal size distribution (CSD) in rocks and the kinetics and dynamics of crystallization II: Makaopuhi lava lake. Contributions to Mineralogy and Petrology, 99, 292-305, http:// dx.doi.org/10.1007/BF00375363

Castillo, P. R. 2012. Adakite petrogenesis. Lithos, 134-135, 304-316, http://dx.doi.org/10.1016/j. lithos.2011.09.013

Castro, A., Vogt, K. \& Gerya, T. 2013. Generation of new continental crust by sublithospheric silicic-magma relamination in arcs: a test of Taylor's andesite model. Gondwana Research, 23, 1554-1566, http://dx.doi. org/10.1016/j.gr.2012.07.004

Cawood, P. A., Hawkesworth, C. J. \& Dhuime, B. 2013. The continental record and the generation of continental crust. Geological Society of America Bulletin, 125, 14-32, http://dx.doi.org/10.1130/B30722.1

Condomines, M., Hemond, C. \& Allègre, C. J. 1988. $\mathrm{U}-\mathrm{Th}-\mathrm{Ra}$ radioactive disequilibria and magmatic processes. Earth and Planetary Science Letters, 90, 243-262, http://dx.doi.org/10.1016/0012-821X(88) 90129-X

Condomines, M., Gauthier, P. J. \& Sigmarsson, O. 2003. Timescales of magma chamber processes and dating of young volcanic rocks. In: BOURDON, B., Henderson, G. M., Lundstrom, C. C. \& Turner, S. P. (eds) Uranium-Series Geochemistry. Reviews in Mineralogy and Geochemistry. The Mineralogical Society of America, Washington, DC, 125-174.

Costa, F., Chakraborty, S. \& Dohmen, R. 2003. Diffusion coupling between trace and major elements and a model for calculation of magma residence times using plagioclase. Geochimica et Cosmochimica Acta, 67, 2189-2200, http://dx.doi.org/10.1016/ S0016-7037(02)01345-5

Davidson, J. P. \& TePley, F. J. 1997. Recharge in volcanic systems: evidence from isotope profiles of phenocrysts. Science, 275, 826-829, http://dx.doi.org/10. 1126 /science. 275.5301 .826

Davidson, J., Turner, S., Handley, H., MacPherson, C. \& Dosseto, A. 2007. Amphibole 'sponge' in arc crust?
Geology, 35, 787-790, http://dx.doi.org/10.1130/ G23637A.1

Defant, M. \& Drummond, M. 1990. Derivation of some modern arc magmas by melting of young subducted lithosphere. Nature, 347, 662-665.

Donn, W. L., Donn, B. D. \& Valentine, W. G. 1965. On the Early History of the Earth. Geological Society of America Bulletin, 76, 287-306, http://dx.doi.org/10. 1130/0016-7606(1965)76[287:OTEHOT]2.0.CO;2

Dosseto, A. \& Turner, S. 2013. Reappraisal of uraniumseries isotope data in Kamchatka lavas: implications for continental arc magma genesis. In: GómeZ-TuENA, A., Straub, S. M. \& Zellmer, G. F. (eds) Orogenic Andesites and Crustal Growth. Geological Society, London, Special Publications, 385. First published online June 11, 2013, http://dx.doi.org/10.1144/ SP385.5

Dosseto, A., Bourdon, B., Joron, J.-L. \& Dupré, B. 2003. U-TH-PA-RA study of the Kamchatka arc: new constraints on the genesis of arc lavas. Geochimica et Cosmochimica Acta, 67, 2857-2877, http:// dx.doi.org/10.1016/S0016-7037(03)00086-3

EICHELberger, J. C. 1978. Andesitic volcanism and crustal evolution. Nature, 275, 21-27, http://dx.doi. org $/ 10.1038 / 275021 \mathrm{a} 0$

Elburg, M. A., Smet, I. \& Pelsmaeker, E. D. 2013. Influence of source materials and fractionating assemblage on magmatism along the Aegean Arc, and implications for crustal growth. In: Gómez-Tuena, A., Straub, S. M. \& Zellmer, G. F. (eds) Orogenic Andesites and Crustal Growth. Geological Society, London, Special Publications, 385. First published online May 30, 2013, http://dx.doi.org/10.1144/SP385.1

Elkins-Tanton, L. T. 2007. Continental magmatism, volatile recycling, and a heterogeneous mantle caused by lithospheric gravitational instabilities. Journal of Geophysical Research, 112, B03405, http://dx.doi.org/10.1029/2005JB004072

Elliott, T., Plank, T., Zindler, A., White, W. \& Bourdon, B. 1997. Element transport from slab to volcanic front at the Mariana arc. Journal of Geophysical Research, 102, 14 991-15019.

Fedotov, S. A., Gorel'chik, V. I., Stepanov, V. V. \& Garbuzova, V. T. 1983. The development of the great Tolbachik fissure eruption in 1975 from seismological data. In: Fedotov, S. A. \& MARKhinin, Y. K. (eds) The Great Tolbachik Fissure Eruption. Cambridge University Press, Cambridge, 189-203.

Gaetani, G. A. \& Grove, T. L. 1998. The influence of water on melting of mantle peridotite. Contributions to Mineralogy and Petrology, 131, 323-346.

Gerya, T. V. \& Yuen, D. A. 2003. Rayleigh-Taylor instabilities from hydration and melting propel 'cold plumes' at subduction zones. Earth and Planetary Science Letters, 212, 47-62, http://dx.doi.org/10. 1016/S0012-821X(03)00265-6

Gerya, T. V., Yuen, D. A. \& Sevre, E. O. D. 2004. Dynamical causes for incipient magma chambers above slabs. Geology, 32, 89-92, http://dx.doi.org/10. 1130/G20018.1

GHIORSo, M. S. \& SACK, R. O. 1995. Chemical mass transfer in magmatic processes IV. A revised and internally consistent thermodynamic model for the interpolation and extrapolation of liquid-solid equilibria in 
magmatic systems at elevated temperatures and pressures. Contributions to Mineralogy and Petrology, 119, 197-212, http://dx.doi.org/10.1007/BF00307281

Ghiorso, M. S., Hirschmann, M. M., Reiners, P. W. \& Kress, V. C. 2002. The pMELTS: a revision of MELTS for improved calculation of phase relations and major element partitioning related to partial melting of the mantle to $3 \mathrm{GPa}$. Geochemistry, Geophysics, Geosystems, 3, 1-35, http://dx.doi.org/10. 1029/2001GC000217

Gill, J. 1981. Orogenic Andesites and Plate Tectonics. Springer, Berlin.

Gómez-Tuena, A., Mori, L., Rincón-Herrera, N. E., Ortega-Guitérrez, F., Solé, J. \& Iriondo, A. 2008. The origin of a primitive trondhjemite from the Trans-Mexican Volcanic Belt and its implications for the construction of a modern continental arc. Geology, 36, 471-474.

Gómez-Tuena, A., Mori, L., Goldstein, S. L. \& Pérez-Arvizu, O. 2011. Magmatic diversity of western Mexico as a function of metamorphic transformations in the subducted oceanic plate. Geochimica et Cosmochimica Acta, 75, 213-241, http://dx.doi. org/10.1016/j.gca.2010.09.029

Gómez-Tuena, A., Díaz-Bravo, B., Vázquez-Duarte, A., PÉrez-Arvizu, O. \& Mori, L. 2013. Andesite petrogenesis by slab-derived plume pollution of a continental rift. In: Gómez-Tuena, A., Straub, S. M. \& Zellmer, G. F. (eds) Orogenic Andesites and Crustal Growth. Geological Society, London, Special Publications, 385. First published online June 11, 2013, http://dx.doi.org/10.1144/SP385.4

Goss, A. R. \& KAY, S. M. 2006. Steep REE patterns and enriched $\mathrm{Pb}$ isotopes in southern Central American arc magmas: evidence for forearc subduction erosion? Geochemistry, Geophysics, Geosystems, 7, http://dx. doi.org/10.1029/2005GC001163

Greene, A. R., DeBari, S. M., Kelemen, P. B., Blusztajn, J. \& Clift, P. D. 2006. A detailed geochemical study of Island Arc Crust: the Talkeetna Arc Section, SouthCentral Alaska. Journal of Petrology, 47, 1051-1093, http://dx.doi.org/10.1093/petrology/egl002

Grove, T. L., Till, C. B. \& Krawczynski, M. J. 2012. The role of $\mathrm{H}_{2} \mathrm{O}$ in subduction zone magmatism. Annual Review of Earth and Planetary Sciences, 40, 413-439, http://dx.doi.org/10.1146/annurev-earth042711-105310

HaAse, K. M., Krumm, S., Regelous, M. \& Joachimski, M. 2011. Oxygen isotope evidence for the formation of silicic Kermadec island arc and Havre-Lau backarc magmas by fractional crystallisation. Earth and Planetary Science Letters, 309, 348-355, http://dx.doi.org/ 10.1016/j.epsl.2011.07.014

HACKer, B. R. 2008. $\mathrm{H}_{2} \mathrm{O}$ subduction beyond arcs. Geochemistry, Geophysics, Geosystems, 9, http://dx.doi. org/10.1029/2007GC001707

Hacker, B. R., Kelemen, P. B. \& Behn, M. D. 2011. Differentiation of the continental crust by relamination. Earth and Planetary Science Letters, 307, 501-516, http://dx.doi.org/10.1016/j.epsl.2011.05.024

Harrison, T. M. 2009. The Hadean Crust: evidence from $>4$ Ga Zircons. Annual Review of Earth and Planetary Sciences, 37, 479-505, http://dx.doi.org/10.1146/ annurev.earth.031208.100151
Hermann, J. \& Spandler, C. 2008. Sediment melts at sub-arc depths: an experimental study. Journal of Petrology, 49, 717-740.

Higgins, M. D. 1996. Magma dynamics beneath Kameni volcano, Thera, Greece, as revealed by crystal size and shape measurements. Journal of Volcanology and Geothermal Research, 70, 37-48, http://dx.doi. org/10.1016/0377-0273(95)00045-3

Hildreth, W. \& Moorbath, S. 1988. Crustal contributions to arc magmatism in the Andes of central Chile. Contributions to Mineralogy and Petrology, 98, 455-489.

Hirose, K. 1997. Melting experiments on lherzolite KLB-1 under hydrous conditions and generation of high-magnesian andesites. Geology, 25, 42-44.

Hofmann, A. W. 1988. Chemical differentiation of the Earth: the relationship between mantle, continental crust, and oceanic crust. Earth and Planetary Science Letters, 90, 297-314, http://dx.doi.org/10.1016/ 0012-821X(88)90132-X

Huybers, P. \& Langmuir, C. 2009. Feedback between deglaciation, volcanism, and atmospheric $\mathrm{CO}_{2}$. Earth and Planetary Science Letters, 286, 479-491, http:// dx.doi.org/10.1016/j.epsl.2009.07.014

Ishizuka, O., Taylor, R. N., Yuasa, M. \& Ohara, Y. 2011. Making and breaking an island arc: a new perspective from the Oligocene Kyushu-Palau arc, Philippine Sea. Geochemistry, Geophysics, Geosystems, 12, http://dx.doi.org/10.1029/2010GC003440

Jull, M. \& Kelemen, P. B. 2001. On the conditions for lower crustal convective instability. Journal of Geophysical Research, 106, 6423-6446, http://dx.doi. org/10.1029/2000JB900357

KAY, R. 1978. Aleutian magnesian andesites: melts from subduction Pacific Oceanic crust. Journal of Volcanology and Geothermal Research, 4, 117-132.

KAY, R. \& KAY, S. 1993. Delamination and delamination magmatism. Tectonophysics, 219, 177-189.

Kay, S. M., MPodozis, C. \& GardeweG, M. 2013. Magma sources and tectonic setting of Central Andean andesites $\left(25.5-28^{\circ} \mathrm{S}\right)$ related to crustal thickening, forearc subduction erosion and delamination. In: GómEZTuena, A., Straub, S. M. \& Zellmer, G. F. (eds) Orogenic Andesites and Crustal Growth. Geological Society, London, Special Publications, 385. First published online August 7, 2013, http://dx.doi.org/10. 1144/SP385.11

Kelemen, P. B. 1995. Genesis of high Mg\# andesites and the continental crust. Contributions to Mineralogy and Petrology, 120, 1-19, http://dx.doi.org/10.1007/ BF00311004

Kelemen, P. B., Yogodzinksi, G. \& Scholl, D. W. 2003. Along-strike Variation in the Aleutian Island Arc: genesis of high-mg\# andesite and implication for the continental crust. In: EILER, J. (ed.) Inside the Subduction Factory. Geophysical Monograph. American Geophysical Union, Washington, DC, 223-276.

Keller, C. B. \& Schoene, B. 2012. Statistical geochemistry reveals disruption in secular lithospheric evolution about $2.5 \mathrm{Gyr}$ ago. Nature, 485, 490-493, http://dx.doi.org/10.1038/nature11024

Kennett, J. P. \& Thunell, R. C. 1977. On explosive Cenozoic Volcanism and climatic implications. 
Science, 196, 1231-1234, http://dx.doi.org/10.1126/ science.196.4295.1231

Kent, A. J. K. 2013. Preferential eruption of andesitic magmas: Implications for volcanic magma fluxes at convergent margins. In: Gómez-Tuena, A., Straub, S. M. \& Zellmer, G. F. (eds) Orogenic Andesites and crustal Growth. Geological Society, London, Special Publications, 385. First published online September 12, 2013, http://dx.doi.org/10.1144/SP385.10

Kent, A. J. R., Darr, C., Koleszar, A. M., Salisbury, M. J. \& CoOper, K. M. 2010. Preferential eruption of andesitic magmas through recharge filtering. Nature Geoscience, 3, 631-636, http://dx.doi.org/10.1038/ ngeo924

Kessel, R., Schmidt, M., Ulmer, P. \& Pettke, T. 2005. Trace element signature of subduction-zone fluids, melts and supercritical liquids at $120-180 \mathrm{~km}$ depth. Nature, 437, 724-727.

Klimm, K., Blundy, J. \& Green, T. 2008. Trace element partitioning and accessory phase saturation during $\mathrm{H}_{2} \mathrm{O}$-saturated melting of basalt with implications for subduction zone chemical fluxes. Journal of Petrology, 49, 523-553.

Kodaira, S., Sato, T., Takahashi, N., Ito, A., Tamura, Y., Tatsumi, Y. \& Kaneda, Y. 2007. Seismological evidence for variable growth of crust along the Izu intraoceanic arc. Journal of Geophysical Research: Solid Earth, 112, http://dx.doi.org/10.1029/2006 JB004593

Kutterolf, S., Jegen, M., Mitrovica, J. X., KwasNitschKa, T., Freundt, A. \& Huybers, P. J. 2013. A detection of Milankovitch frequencies in global volcanic activity. Geology, 41, 227-230, http://dx.doi. org $/ 10.1130 / \mathrm{G} 33419.1$

LASAGA, A. C. 1983. Geospeedometry: an extension of geothermometry. In: SAXENA, S. K. (ed.) Kinetics and Equilibrium in Mineral Reactions. Springer, New York, 81-114.

Lee, J., Stern, R. J. \& Bloomer, S. H. 1995. Forty million years of magmatic evolution in the Mariana arc: the tephra glass record. Journal of Geophysical Research: Solid Earth, 100, 17 671-17 687, http://dx.doi.org/ 10.1029/95JB01685

Leeman, W. P. 1983. The influence of crustal structure on compositions of subduction-related magmas. Journal of Volcanology and Geothermal Research, $\mathbf{1 8}$, 561-588, http://dx.doi.org/10.1016/0377-0273(83) 90026-4

MacPherson, C., Dreher, S. \& Thirlwall, M. F. 2006. Adakites without slab melting: high pressure differentiation of island arc magma, Mindanao, the Philippines. Earth and Planetary Science Letters, 243, 581-593.

Marschall, H. R. \& Schumacher, J. C. 2012. Arc magmas sourced from melange diapirs in subduction zones. Nature Geoscience, 5, 862-867, http://dx.doi. org/10.1038/ngeo1634

Miller, D. M., Goldstein, S. L. \& Langmuir, C. 1994. Cerium/lead and lead isotope ratios in arc magmas and the enrichment of $\mathrm{Pb}$ in the continents. Nature, $\mathbf{3 6 8}$, 514-520.

Morgan, D. J. \& Blake, S. 2006. Magmatic residence times of zoned phenocrysts: introduction and application of the binary element diffusion modelling (BEDM) technique. Contributions to Mineralogy and
Petrology, 151, 58-70, http://dx.doi.org/10.1007/ s00410-005-0045-4

Mori, L., Gómez-Tuena, A., Schaaf, P., Goldstein, S. L., Pérez-Arvizu, O. \& Solís-Pichardo, G. 2009. Lithospheric removal as a trigger for flood basalt magmatism in the Trans-Mexican Volcanic Belt. Journal of Petrology, 50, 2157-2186, http:// dx.doi.org/10.1093/petrology/egp072

Morris, J., Leeman, W. \& Tera, F. 1990. The subducted component in island arc lavas: cEonstraints from Be isotopes and B-Be systematics. Nature, 344, 31-36.

Müntener, O., Kelemen, P. \& Grove, T. 2001. The role of $\mathrm{H}_{2} \mathrm{O}$ during crystallization of primitive arc magmas under uppermost mantle conditions and genesis of igneous pyroxenites: an experimental study. Contributions to Mineralogy and Petrology, 141, 643-658.

Newman, S., Macdougall, J. D. \& Finkel, R. C. 1984. ${ }^{230} \mathrm{Th}-{ }^{238} \mathrm{U}$ disequilibrium in island arcs: evidence from the Aleutians and the Marianas. Nature, 308, 268-270, http://dx.doi.org/10.1038/308268a0

Nishimoto, S., Ishikawa, M., Arima, M. \& Yoshida, T. 2005. Laboratory measurement of P-wave velocity in crustal and upper mantle xenoliths from Ichino-megata, NE Japan: ultrabasic hydrous lower crust beneath the NE Honshu arc. Tectonophysics, 396, 245-259, http://dx.doi.org/10.1016/j.tecto.2004.12.010

Ortega-Gutiérrez, F., Elías-Herrera, M. \& DávalosElizondo, M. G. 2008. On the nature and role of the lower crust in the volcanic front of the Trans-Mexican Volcanic Belt and its fore-arc region, southern and central Mexico. Revista Mexicana de Ciencias Geológicas, 25, 346-364.

Parman, S. \& Grove, T. 2004. Harzburgite melting with and without $\mathrm{H}_{2} \mathrm{O}$ : experimental data and predictive modeling. Journal of Geophysical Research, 109, http://dx.doi.org/10.1029/2003JB002566

PlanK, T. 2005. Constraints from thorium/lanthanum on sediment recycling at subduction zones and the evolution of the continents. Journal of Petrology, 46, 921-944, http://dx.doi.org/10.1093/petrology/egi005

Plank, T. \& Langmuir, C. H. 1988. An evaluation of the global variations in the major element chemistry of arc basalts. Earth and Planetary Science Letters, 90, 349-370, http://dx.doi.org/10.1016/0012-821X(88) 90135-5

Plank, T. \& LangmuiR, C. H. 1993. Tracing trace elements from sediment input to volcanic output at subduction zones. Nature, 362, 739-743, http://dx. doi.org/10.1038/362739a0

Plank, T. \& Langmuir, C. 1998. The chemical composition of subducting sediment and its consequences for the crust and mantle. Chemical Geology, 145, $325-394$.

Plank, T., Cooper, L. B. \& Manning, C. E. 2009. Emerging geothermometers for estimating slab surface temperatures. Nature Geoscience, 2, 611-615, http://dx.doi.org/10.1038/ngeo614

Plank, T., Kelley, K. A., Zimmer, M. M., Hauri, E. H. \& Wallace, P. J. 2013. Why do mafic arc magmas contain $\sim 4 \mathrm{wt} \%$ water on average? Earth and Planetary Science Letters, 364, 168-179, http://dx.doi. org/10.1016/j.epsl.2012.11.044

Ranero, C. R., Phipps Morgan, J., McIntosh, K. \& Reichert, C. 2003. Bending, faulting and mantle 
serpentinization at ocean trenches. Nature, $\mathbf{4 2 5}$, $367-373$.

Rapp, R., Shimizu, N. \& Norman, M. 2003. Growth of early continental crust by partial melting of eclogite. Nature, 425, 605-609.

Reubi, O. \& Blundy, J. 2009. A dearth of intermediate melts at subduction zone volcanoes and the petrogenesis of arc andesites. Nature, 461, 1269-1273, http://dx.doi.org/10.1038/nature08510

RingWOOD, A. E. 1974. The petrological evolution of island arc systems: twenty-seventh William Smith Lecture. Journal of the Geological Society, London, 130, 183-204, http://dx.doi.org/10.1144/gsjgs.130. 3.0183

RUDNICK, R. L. 1995. Making continental crust. Nature, 378, 571-578, http://dx.doi.org/10.1038/ $378571 \mathrm{a} 0$

Rudnick, R. \& GAO, S. 2003. Composition of the continental crust. In: RudNick, R. (ed.) Treatise on Geochemistry. Elsevier, Oxford, 1-64.

Ruprecht, P. \& Plank, T. 2013. Feeding andesitic eruptions with a high-speed connection from the mantle. Nature, 500, 68-72, http://dx.doi.org/10.1038/ nature 12342

Ruscitto, D. M., Wallace, P. J., Cooper, L. B. \& Plank, T. 2012. Global variations in $\mathrm{H}_{2} \mathrm{O} / \mathrm{Ce}$ : 2. Relationships to arc magma geochemistry and volatile fluxes. Geochemistry, Geophysics, Geosystems, 13, http://dx.doi.org/10.1029/2011GC003887

Savov, I. P., Ryan, J. G., D’ Antonio, M., Kelley, K. \& Mattie, P. 2005. Geochemistry of serpentinized peridotites from the Mariana Forearc Conical Seamount, ODP Leg 125: implications for the elemental recycling at subduction zones. Geochemistry, Geophysics, Geosystems, 6, http://dx.doi.org/10.1029/ 2004GC000777

SchmidT, M. \& Poli, S. 1998. Experimentally based water budgets for dehydrating slabs and consequences for arc magma generation. Earth and Planetary Science Letters, 163, 361-379.

Schmitт, A. K. 2011. Uranium series accessory crystal dating of magmatic processes. Annual Review of Earth and Planetary Sciences, 39, 321-349, http:// dx.doi.org/10.1146/annurev-earth-040610-133330

Shibata, T., Yoshikawa, M., Itoh, J., Ujike, O., Miyoshi, M. \& TaKemura, K. 2013. Along-arc geochemical variations in Quaternary magmas of northern Kyushu Island, Japan. In: GómeZ-Tuena, A., STRAub, S. M. \& Zellmer, G. F. (eds) Orogenic Andesites and Crustal Growth. Geological Society, London, Special Publications, 385. First published online August 15, 2013, http://dx.doi.org/10.1144/SP385.13

Sigmarsson, O., Martin, H. \& Knowles, J. 1998. Melting of a subducting oceanic crust from U-Th disequilibria in austral Andean lavas. Nature, 394, 566-569.

Singer, B. S., Jicha, B. R. ET AL. 2013. Lying in wait: deep and shallow evolution of dacite beneath Volcán de Santa María, Guatemala. In: GómezTuena, A., Straub, S. M. \& Zellmer, G. F. (eds) Orogenic Andesites and Crustal Growth. Geological Society, London, Special Publications, 385. First published online June 11, 2013, http://dx.doi.org/10. $1144 /$ SP385.2
Smith, I. E. M. 2013. High-magnesium andesites: the example of the Papuan Volcanic Arc. In: GómezTuena, A., Straub, S. M. \& Zellmer, G. F. (eds) Orogenic Andesites and Crustal Growth. Geological Society, London, Special Publications, 385. First published online July 31, 2013, http://dx.doi.org/10. $1144 /$ SP385.7

Steiner, A. \& Streck, M. J. 2013. The Strawberry Volcanics: generation of 'orogenic' andesites from tholeiite within an intra-continental volcanic suite centred on the Columbia River flood basalt province, USA. In: Gómez-Tuena, A., Straub, S. M. \& Zellmer, G. F. (eds) Orogenic Andesites and Crustal Growth. Geological Society, London, Special Publications, 385. First published online August 6, 2013, http://dx.doi. org/10.1144/SP385.12

Stern, R. J. \& SCHOLL, D. W. 2010. Yin and yang of continental crust creation and destruction by plate tectonic processes. International Geology Review, 52, 1-31, http://dx.doi.org/10.1080/00206810903332322

Stern, R. J., TAmura, Y. ET AL. 2013. Volcanoes of the Diamante cross-chain: evidence for a mid-crustal felsic magma body beneath the Southern IzuBonin-Mariana arc. In: Gómez-Tuena, A., Straub, S. M. \& Zellmer, G. F. (eds) Orogenic Andesites and Crustal Growth. Geological Society, London, Special Publications, 385. First published online June 27, 2013, http://dx.doi.org/10.1144/SP385.6

Straub, S. M. 2003. The evolution of the Izu BoninMariana volcanic arcs (NW Pacific) in terms of major elements. Geochemistry, Geophysics, Geosystems, 4, 1018, http://dx.doi.org/10.1029/2002GC000357

Straub, S. M. \& Layne, G. D. 2003. The systematics of chlorine, fluorine, and water in Izu arc front volcanic rocks: implications for volatile recycling in subduction zones. Geochimica et Cosmochimica Acta, 67, 4179-4203, http://dx.doi.org/10.1016/ S0016-7037(03)00307-7

Straub, S. M. \& Zellmer, G. F. 2012. Volcanic arcs as archives of plate tectonic change. Gondwana Research, 21, 495-516, http://dx.doi.org/10.1016/j. gr.2011.10.006

Straub, S. M., Goldstein, S. L., Class, C., Schmidt, A. \& Gómez-Tuena, A. 2010. Slab and mantle controls on the $\mathrm{Sr}-\mathrm{Nd}-\mathrm{Pb}-\mathrm{Hf}$ isotope evolution of the post $42 \mathrm{Ma}$ Izu-Bonin Volcanic Arc. Journal of Petrology, 51, 993-1026, http://dx.doi.org/10.1093/petrology/ egq009.

Straub, S. M., Gómez-Tuena, A., Stuart, F. M., Zellmer, G. F., Espinasa-Perena, R., CaI, Y. \& IIZUKA, Y. 2011. Formation of hybrid arc andesites beneath thick continental crust. Earth and Planetary Science Letters, 303, 337-347, http://dx.doi.org/10. 1016/j.epsl.2011.01.013

Straub, S. M., Zellmer, G. F., Gómez-Tuena, A., Espinasa-Pereña, R., Martin-Del Pozzo, A. L., Stuart, F. M. \& Langmuir, C. H. 2013. A genetic link between silicic slab components and calc-alkaline arc volcanism in central Mexico. In: Gómez-Tuena, A., Straub, S. M. \& Zellmer, G. F. (eds) Orogenic Andesites and Crustal Growth. Geological Society, London, Special Publications, 385. First published online September 12, 2013, http://dx.doi.org/10. 1144/SP385.14 
TAtsumi, Y. \& EgGins, S. 1995. Subduction Zone Magmatism, Hoffman, P., Jeanloz, R. \& Knoll, A. (eds) Blackwell Science, Cambridge.

Tatsumi, Y., Shukuno, H., Tani, K., Takahashi, N., KodaIRa, S. \& Kogiso, T. 2008. Structure and growth of the Izu-Bonin-Mariana arc crust: 2. Role of crust-mantle transformation and the transparent Moho in arc crust evolution. Journal of Geophysical Research: Solid Earth, 113, http://dx.doi.org/10. 1029/2007JB005121

TAYLOR, S. R. 1967. The origin and growth of continents. Tectonophysics, 4, 17-34, http://dx.doi.org/10.1016/ 0040-1951(67)90056-X

TAYlor, S. R. \& McLennan, S. M. 1995. The geochemical evolution of the continental crust. Reviews of Geophysics, 33, 241-265, http://dx.doi.org/10.1029/ 95RG00262

Tera, F., Brown, L., Morris, J., SACKs, I. S., Klein, J. \& MidDleton, R. 1986. Sediment incorporation in island arc magmas: inferences from Be-10. Geochimica et Cosmochimica Acta, 50, 535-550.

Thorpe, R. S. 1982. Andesites. Orogenic Andesites and Related Rocks (1st edn). John Wiley \& Sons, Chichester.

Tonarini, S., Leeman, W. P. \& Leat, P. T. 2011. Subduction erosion of forearc mantle wedge implicated in the genesis of the South Sandwich Island (SSI) arc: evidence from boron isotope systematics. Earth and Planetary Science Letters, 301, 275-284, http:// dx.doi.org/10.1016/j.eps1.2010.11.008

Turner, S., Hawkesworth, C., van Calsteren, P., Heath, E., Macdonald, R. \& Black, S. 1996. U-series isotopes and destructive plate margin magma genesis in the Lesser Antilles. Earth and Planetary Science Letters, 142, 191-207, http://dx.doi. org/10.1016/0012-821X(96)00078-7

Turner, S., HaWkesworth, C. ET AL. 1997. ${ }^{238}{ }^{2}-{ }^{230}$ Th disequilibria, magma petrogenesis, and flux rates beneath the depleted Tonga-Kermadec island arc. Geochimica et Cosmochimica Acta, 61, 4855-4884, http://dx.doi.org/10.1016/S0016-7037(97)00281-0

Turner, S. P., George, R. M. M., Evans, P. J., HawkesWORTh, C. J. \& Zellmer, G. F. 2000. Time-scales of magma formation, ascent and storage beneath subduction-zone volcanoes. Philosophical Transactions of the Royal Society of London. Series A: Mathematical, Physical and Engineering Sciences, 358, 1443-1464, http://dx.doi.org/10.1098/rsta.2000.0598

Turner, S. P., Bourdon, B. \& Gill, J. 2003. Insights into magma genesis at convergent margins from U-series isotopes. In: Bourdon, B., HeNderson, G. M., LundStrom, C. C. \& Turner, S. P. (eds) Uranium Series Geochemistry. Reviews in Mineralogy and Geochemistry. The Mineralogical Society of America, Washington, DC, 255-315.

Wade, J. A., Plank, T. et AL. 2005. The May 2003 eruption of Anatahan volcano, Mariana Islands: geochemical evolution of a silicic island-arc volcano. Journal of Volcanology and Geothermal Research, 146, 139-170, http://dx.doi.org/10.1016/j.jvolgeores. 2004.11.035

Wilde, S. A., Valley, J. W., Peck, W. H. \& Graham, C. M. 2001. Evidence from detrital zircons for the existence of continental crust and oceans on the Earth 4.4
Gyr ago. Nature, 409, 175-178, http://dx.doi.org/ $10.1038 / 35051550$

Yoshida, T., Kimura, J.-I. ET AL. 2013. Evolution of the Late Cenozoic Magmatism and the Crust-Mantle structure in the NE Japan Arc. In: Gómez-TuenA, A., Straub, S. M. \& Zellmer, G. F. (eds) Orogenic Andesites and Crustal Growth. Geological Society, London, Special Publications, 385. First published online September 24, 2013, http://dx.doi.org/10. 1144/SP385.15.

Zandt, G., Gilbert, H., Owens, T. J., Ducea, M., Saleeby, J. \& Jones, C. H. 2004. Active foundering of a continental arc root beneath the southern Sierra Nevada in California. Nature, 431, 41-46, http://dx. doi.org/10.1038/nature 02847

Zellmer, G. F. 2008. Some first-order observations on magma transfer from mantle wedge to upper crust at volcanic arcs. In: ANNEN, C. \& Zellmer, G. F. (eds) Dynamics of Crustal Magma Transfer, Storage and Differentiation. Geological Society, London, Special Publications, 304, 15-31, http://dx.doi.org/10. 1144/SP304.2

Zellmer, G., Turner, S. \& Hawkesworth, C. 2000. Timescales of destructive plate margin magmatism: new insights from Santorini, Aegean volcanic arc. Earth and Planetary Science Letters, 174, 265-281, http://dx.doi.org/10.1016/S0012-821X(99)00266-6

Zellmer, G., Sparks, R., Hawkesworth, C. \& WiedeNBECK, M. 2003. Magma emplacement and remobilization time scales beneath Montserrat: insights from $\mathrm{Sr}$ and $\mathrm{Ba}$ zonation in plagioclase phenocrysts. Journal of Petrology, 44, 1413-1431.

Zellmer, G. F., Annen, C., Charlier, B. L. A., George, R. M. M., Turner, S. P. \& Hawkesworth, C. J. 2005. Magma evolution and ascent at volcanic arcs: constraining petrogenetic processes through rates and chronologies. Journal of Volcanology and Geothermal Research, 140, 171-191, http://dx.doi.org/10.1016/ j.jvolgeores.2004.07.020

Zellmer, G. F., IizuKa, Y., Miyoshi, M., Tamura, Y. \& TATsumi, Y. 2012. Lower crustal $\mathrm{H}_{2} \mathrm{O}$ controls on the formation of adakitic melts. Geology, 40, 487-490, http://dx.doi.org/10.1130/G32912.1

Zellmer, G. F., Freymuth, H., Cembrano, J. M., Clavero, J. E., Veloso, E. A. E. \& Sielfeld, G. G. 2013a. Altered mineral uptake into fresh arc magmas: insights from U-Th isotopes of samples from Andean volcanoes under differential crustal stress regimes. In: Gómez-Tuena, A., Straub, S. M. \& Zellmer, G. F. (eds) Orogenic Andesites and Crustal Growth. Geological Society, London, Special Publications, 385. First published online July 18, 2013, http://dx.doi.org/10.1144/SP385.9

Zellmer, G. F., Sakamoto, N., Iizuka, Y., Miyoshi, M., Tamura, Y., Hsieh, H.-H. \& Yurimoto, H. $2013 b$. Crystal uptake into aphyric arc melts: insights from two-pyroxene pseudo-decompression paths, plagioclase hygrometry, and measurement of hydrogen in olivines from mafic volcanics of SW Japan. In: Gómez-Tuena, A., Straub, S. M. \& Zellmer, G. F. (eds) Orogenic Andesites and Crustal Growth. Geological Society, London, Special Publications, 385. First published online June 11, 2013, http://dx.doi. org/10.1144/SP385.3 